\title{
The Influence of Political Factors on the Architecture of Ducal Castles Owned by the Griffin Dynasty
}

\author{
Jakub Ignacy Gołębiewski \\ Department of Architecture and Urban Planning, West Pomeranian University of Technology in Szczecin, \\ 70-310 Szczecin, Poland; jgolebiewski@zut.edu.pl; Tel.: +48-692-400-944
}

Received: 6 November 2020; Accepted: 27 November 2020; Published: 1 December 2020

\begin{abstract}
The subject of the article is an analysis of the ideological and political factors that influenced the architectural transformation of ducal residences which belonged to the Griffin dynasty during the Prussian-German and later Polish rule. The article verifies the scale of this impact and the formal effects of actions taken in the context of the entire Pomeranian Duchy. The research is based on a selected set of ducal castles from the Pomeranian region and uses analytical and comparative methods. In the course of the research, it was possible to confirm the influence of political and ideological factors on the status of the preserved heritage of the Pomeranian Dukes, both on the part of the Prussian-German and Polish authorities. In both cases, these actions were caused by the desire to take over symbolic control over the space after territorial changes. These actions were aimed either at eliminating elements foreign to a given nation and state from the cultural landscape of Pomerania or at their transformation and familiarization. In the process of transforming ducal castles, utility factors also played a significant role in the Prussian-German period, while after 1945 the important factor was the then conservation doctrine.
\end{abstract}

Keywords: architecture; West Pomerania; the Griffin dynasty; policy; cultural space; Prussian absolutism; reconstruction; conservation of monuments

\section{Introduction}

In a broader context, this article focuses on the influence of power and political relations on the form of national heritage in the European cultural area. Throughout the centuries, Europe has been the scene of many struggles between the tribes and nations inhabiting it, and the borders of individual territories have changed many times, often with the use of military force. As a result of these conquests, the elements of the cultural heritage of the conquered peoples found in a given area were often deliberately annihilated or significantly transformed, manifesting the emergence of new authority in a given territory (Bartetzky 2012, pp. 17-32). The language of architecture was used in these activities in various ways. From Roman times, spatial solutions and forms of development characteristic of the territory of the empire were introduced into the conquered lands. They became signs of spatial belonging to the new state. This form of taking control over a given territory and introducing native architectural forms could be observed many times. Furthermore, architectural objects erected in conquered areas were often saturated with symbols and allegories, determining the allegiance to a given state (Norberg-Schulz 1999, pp. 42-43).

The phenomenon can be explained by the division of space into "our own" and "strange", a division which determines to attitude of its actual users. In case space is classified as strange, it needs to be marked and assimilated by the convergence of spatial forms in line with social relations and ideology. The process leads to the adaptation of space to the user's expectations, values, and needs (Jałowiecki 2010, pp. 24-27). There are numerous historical examples of conversion, from rebuilding to complete demolishing. Specific buildings that were symbols of political power or religious cults 
were demolished, rebuilt, or reconstructed (Basista 2009, p. 86). The goal was to achieve symbolic domination over a given space, and thus also over its inhabitants (Wallis 1967, p. 71). Castles, which also acted as centers of power, were particularly vulnerable to this type of conversion.

The area of Western Pomerania, which is currently within the borders of Poland, is an interesting example of the abovementioned dependencies resulting from national and territorial changes (Labuda 1985, pp. 9-14). For centuries, this area has been the arena of struggles between Germanic, Slavic, and Nordic peoples, each of which left their mark on the land (Piskorski 1999, pp. 57-92). From the Middle Ages to modern times, the Slavic Griffin dynasty exercised sovereignty over a large part of Pomerania, a part which was repeatedly Germanized. After the dynasty ended, this area was successively under the rule of Sweden, Prussia, and Germany, and it now belongs to Poland.

The main aim of this article is to show the impact of the political changes and individual governments that reigned in Pomerania after the fall of the Griffin dynasty on the material heritage. The author is interested in ducal residences which have undergone numerous transformations and also been conditioned politically and ideologically. This topic has already been studied many times, but on the sidelines of other scientific research focused on the architectural forms of Pomeranian castles (Dziurla 1959; Radacki 1976; Kroman 1992). The most comprehensive and in-depth analysis of the influence of the Prussian absolutism on Szczecin's urban planning and architecture was presented in the publication "Szczecin barokowy" (Słomiński et al. 2000), while the attitude of Polish authorities and Poles to the post-German cultural space was extensively described in "Między Stettinem a Szczecinem. Metamorfoza miasta od 1945 do 2005" (Musekamp 2013). The issue of the reconstruction of Szczecin's monuments has also been discussed in recent years (Fiuk 2017; Gwiazdowska 2016), which proves that the topic is still relevant and includes many aspects that have not been explored yet. In the context of the research so far, this paper attempts to verify the scale of political and ideological factors in the transformation of ducal architecture throughout history in a broad regional context.

In the first part of the research, the author presents the context of political and national transformations in Pomerania during the reign of the Griffin Dynasty. At that time, relations between the Dukes and Brandenburg as well as the Kingdom of Poland to a large extent determined the future attitude of Germany and Poland to the dynasty's heritage. Another part describes the development of ducal castle architecture during the rule of the Griffins, which is followed by the transformation of the castles during the Prussian-German and Polish periods. The discussion examines the scale of conversion and underlying motivation, while differentiating utility and political factors. The summary attempts to assess the impact of political factors on the architectural form of the ducal castles.

\section{Materials and Methods}

In order to achieve research goals, a comparative analysis of selected examples was conducted. The objects were selected on the basis of the previously formulated classification of ducal castles in Western Pomerania (Radacki 1976, pp. 48-105). Three examples from the present-day territory of Poland (Szczecin, Słupsk, Darłowo) were selected for in-depth study, which allowed for a comparative analysis of the attitude of Prussian-German and Polish authorities towards the Griffins' heritage. The selected buildings were located in the most prominent political centers of the former principality and they were given the most representative character. Therefore, during the German and Polish rule, these castles were subjected to the strongest formal transformation. Castles that remained in Germany after 1945 were excluded from the extensive analysis and so were the castles destroyed by Swedes and Brandenburgers, as well as those in peripheral locations. Nevertheless, in order to obtain a broader background of the phenomenon, the attitude of the German authorities to the castles in Wkryujście (Ückemünde), Wołogoszcz (Wolgast), Szczecinek, and Białogard was also analyzed.

The analysis of individual objects focused on various stages that shaped the form of the ducal residence during the Griffin dynasty (1046-1637), Prussian-German rule (1720-1945), and Polish rule (after 1945). The presentation of the original form of each building allowed for a later comparison of transformations during the Prussian-German period and the Polish period. Selected objects were 
analyzed using historical-interpretative, iconological, and comparative methods. The analysis of the historical and political context was significant in assessing the influence authorities had on the architecture of ducal residences. It should be noted that, in the first phase, the period of Prussian-German rule in Pomerania coincides with the Prussian absolute monarchy (1701-1806), and in the next phase with the German Empire (1871-1918). Both periods are characterized by a significant influence of the central government on architecture (Słomiński et al. 2000; Makała 2011). We can see a similar strong political influence after 1945, when the communist regime influenced the architecture and reconstruction after Poland's recovery of Pomerania. In the above context, an analysis of selected ducal castles focuses on changes to their external form, their functions, and symbolic gestures of the new authorities, which testify to their attitude towards these buildings. This distinction is based on a list of representative architectural values, such as utility, aesthetics, and culture (Basista 2009, p. 39). Then, efforts were made to examine the influence of symbolic gestures on defining the spatial values of ducal architecture. In this case, the distinction of spatial values formulated by Alexander Wallis was used. We can distinguish here functional, existential, and situational values, where situational values are associated with the sense of identification with a given space, while existential values are associated with the sense of social and cultural awareness (Wallis 1990, pp. 28-30).

In the case of the Prussian-German period, the research relied primarily on the query of iconographic and historical sources and their interpretation. In the case of the Polish period, an important source material was the documented attitude of political and conservation authorities towards the ducal heritage. On this basis, attempts were made to define the causes of the transformation. The differentiation between ideological, political, emotional, utility, and objective transformation causes made it possible to define mutual relations between them and provide the final verification and assessment of political and ideological factors and their influence on the shape of the preserved cultural heritage of the Griffins.

\section{Results}

\subsection{The Historical Outline of the Political and National Relations in the Area of Pomerania}

The evaluation of the Prussian and German attitude and the post-1945 attitude of the Polish authorities towards the material heritage of the Griffin dynasty requires a short description of Pomerania's political background (Figure 1). The origins of the dynasty can be traced back to the 12th century. Although the ducal power emerged from a tribal system, it had difficulties in subordinating the local populace. The first historically confirmed duke and vassal of the Polish king Bolesław III Wrymouth was Wartislaw, who belonged to a Slavic dynasty. His duchy consisted of such areas as Szczecin, Kołobrzeg, Pyrzyce, Kamień Pomorski, Dymin, Wołogoszcz, Wolin, and Chocków. From the very beginning, the duchy was weakened under the pressure of Danish and German raids. German influence in Pomerania intensified in the 1230s after the Danish pressure subsided. The German colonization of the cities continued, and parts of the land were given to knights and orders of German origins. These activities were supported by Barnim I and Wartislaw II of Demmin. At that time, individual lands of the duchy were also divided among rich families, and in 1248 the feudal church duchy of the bishop of Kammin was also carved out of these areas. In 1295, the duchy was separated into two districts- the Wolgast district belonging to Bogislaw IV and Otto's Szczecin district (Sławno and Słupsk were added to the Wolgast region of the duchy in 1317). In 1318, with the end of the Ascan dynasty that ruled in Brandenburg, the threat to the duchy subsided. In 1372, the Wolgast duchy was divided into two parts: the western part, up of the Świna river, and the eastern Sławno/Słupsk part. In the 14th century, the threat from the Teutonic Order pressured the dukes to search for a relationship with the Kingdom of Poland. It was solidified by the marriage of Bogislaw $X$ with Anna Jagiellon, the daughter of Casimir IV Jagiellon. Barnim X carried out effective internal and foreign policy based on friendship both with the Polish king as well as with the German emperor. He managed to unite Pomeranian and to prevent its incorporation into Brandenburg, but he had to acknowledge 
the feudal and succession rights of the dangerous neighbor. The descendants of Bogislaw $\mathrm{X}$ bonded the future of the duchy with the German cultural circle by adopting Lutheranism and by marrying representatives of the German ducal families. Near the end of the 16th century, the dynasty began to decline. At the end of his life, Bogislaw XIV, the last ruling duke of Szczecin, was forced to accept the protectorate of Sweden. After his death in 1637, the duchy should have become the property of the Hohenzollern House, but it was instead divided into Swedish and Brandenburg occupational zones. The last representative of the dynasty was Anna von Croÿ, the duchess of Słupsk, who died in 1660.

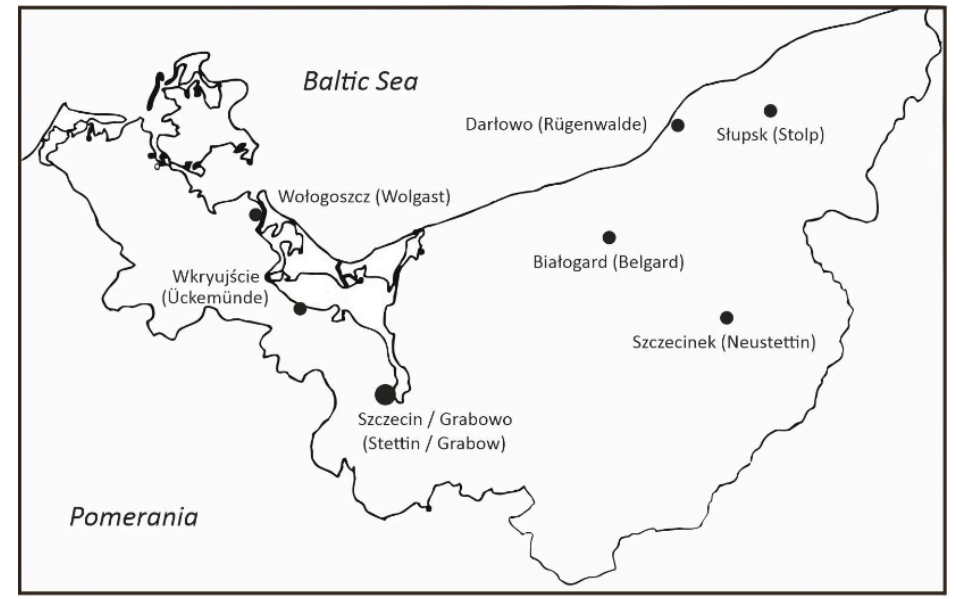

Figure 1. Locations of the prince's castles in Pomerania, created by author.

During their reign, the Griffin dynasty tried to maintain the duchy's independence from its strong neighbors-Mecklenburg, Brandenburg, Denmark, Sweden, and Poland, as well as the State of the Teutonic Order-negotiating political alliances with neighboring states depending on the economic situation. Brandenburg was always the boldest in their claims regarding the Duchy of Pomerania, and the House of Hohenzollern was second. Despite the growing connection of the duchy with the German-speaking area, after the end of the dynasty and after the Swedish episode, Prussian authorities did not treat the Pomeranian lands as a territory returning to its origins but rather as a conquered land that enjoyed a certain degree of autonomy which could not be tolerated any longer. It is possible that this was the reason for the ambivalent attitude of the Prussian authorities towards the Pomeranian Dukes' heritage. After 1945, the Polish authorities had a completely different approach towards the Pomeranian dynasty. Their political goal was to sanction the presence of the Polish nation in the recovered areas as a result of post-war agreements of the great superpowers. To achieve this, a number of historical facts were used, including the Slavic origin of tribes living there in the early Middle Ages, the Slavic origin of the Griffin dynasty, the conquests and periodic rule of the Polish Piast dynasty over Pomerania, and the later political and family connections between Polish rulers and Pomeranian dukes. These factors can help us to understand the approach towards the material heritage of Pomeranian dukes.

\subsection{The Case Study of the Ducal Castle in Szczecin}

\subsubsection{The Ducal Castle in Szczecin during the Rule of the Griffin Dynasty and during the Swedish Rule}

The oldest preserved relics of a ducal residence in Szczecin date back to the half of the 14th century. In 1346, Barnim III signed a pact with the city council allowing him to erect structures by the city wall, within the confines of the former gord at the top of the hill. In 1346-1347, a brick residential house and a castle chapel dedicated to St. Otto were built in the north part of the gord. In 1428-1430, duke Casimir VI recommended to build a "large house" in the south part of the castle hill, but its construction was finished by Bogislaw X in 1491. This was a single-storey rectangular building with a tower situated on the axis extending from the side of the courtyard. The second tower (prison tower) was placed 
by the south-west corner of the wing. Most probably Barnim XI expanded the south wing together with its towers and gave it late Gothic qualities with tracery decorations of roof extensions. The works finished in 1538 (Figure 2a). In 1551, the east wing probably burned down entirely. In 1575-1577, a general transformation and expansion of the castle was initiated by John Frederick. The architects responsible for the works were most probably the master builder Wilhelm Zacharias and Antonio Guglielmo (Arlet 2017, p. 152; Jarzewicz 2019, p. 291), who developed a design that referred to Italian Renaissance. In 1573, the former residential house, the chapel of St. Otto, and the building with the knight hall were demolished. Only the south wing was left, and the reconstruction of the east wing was completed. At the end of the north wing, which featured a new chapel, a new tower was erected. As a result of the expansion, a four-wing residential complex was created with an inner trapezoidal courtyard. At the beginning of the 17th century, the appearance of the south wing changed once again. Octagonal towers were built which were topped with cupolas. In 1616, duke Philip II began another transformation. He added a new wing to the castle on its west side. The construction was finished in 1619 by Francis I. The newly created museum wing was connected to the already existing west wing by two gate connectors. As a result of this transformation, a new courtyard was created, previously called the "crane" courtyard and later the "mint" courtyard. The new west wing gained mansards and side gables with forms clearly referring to Renaissance and North European mannerism (Figure 2b).

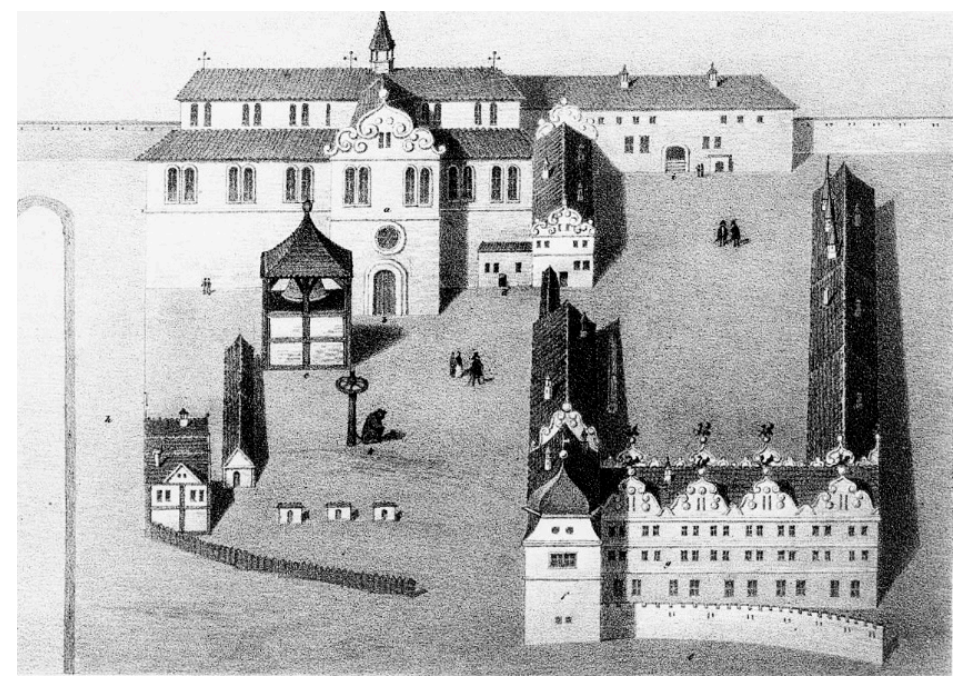

(a)

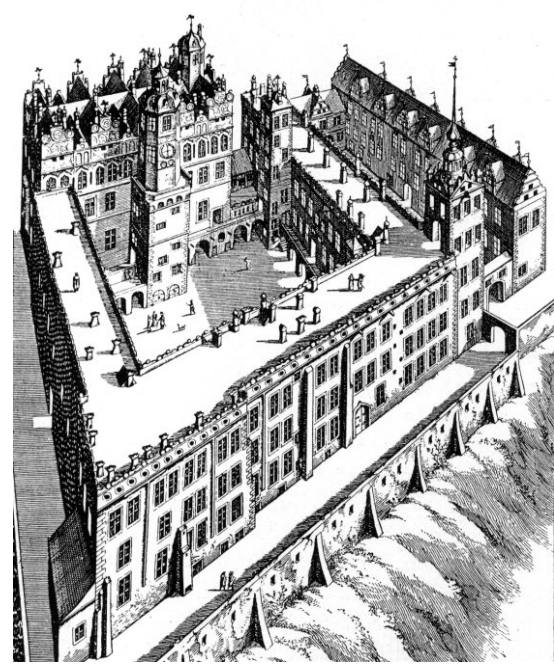

(b)

Figure 2. (a) The Pomeranian Dukes' Castle in Szczecin between 1538 and 1574, source: fotopolska.eu; (b) Matthäus Merian, aerial view of the Pomeranian Dukes' Castle in Szczecin, 1653, source: Wikimedia Commons.

In 1637, after the death of the last of the Griffins-duke Bogislaw XIV-Szczecin came under the rule of Sweden, and the castle became the seat of the royal governor. At the time of the Swedish rule, the castle suffered during the Brandenburg siege of the city in 1677. It is possible that at that time the valuable comb attics of the north wing were destroyed together with the side gables of the west wing, as well as some of the gables of the south wing. The detailed scope of rebuilding remains unknown, but most probably it was limited to securing the damaged fragments of the structure. In 1688, the architect Nicodemus Tessin the Younger developed a design for the conversion of the castle into a Baroque residence. The design assumed, among other things, the demolition of the east and south wing together with the towers (Paszkowska 1992, pp. 117-28). Fortunately, these plans were not implemented. The most valuable souvenir of the Swedish rule over the castle is the astronomical clock, which is placed on the tower of the south wing on the side of the courtyard. During Swedish rule, the castle was not fully utilized by the governor. It also featured warehouses and an armory, which proves that it was no longer a representative residence. 


\subsubsection{The Attitude of Prussian and German Authorities towards the Castle until 1945}

After the peace treaty signed in Stockholm in 1720, Szczecin and the part of Pomerania occupied by Sweden were sold to Prussia. At the beginning of their rule in the city, Prussian authorities had to face the enormous devastation caused by the siege of Szczecin in 1713. Following the words of Henryk Dziurla, "The demolition of partially destroyed old buildings and monuments began, and new houses were erected in their place. The transformation of the castle also started at that time. The biggest changes concerned the south wing. It seems that the traditional forms of native architecture and the coats of arms of Sweden on the face of the clock greatly irritated the Prussian king" (Dziurla 1959, p. 73). Therefore, the author suspects that the transformation did not result only from aesthetic reasons, but also from ideological conditions. The Prussian takeover of the castle was associated not only with the change in its external form, but mainly with the introduction of new functions. The ducal castle was given military, administrative, and residential functions, and occasionally fulfilled a representative role. In 1723, the seat of state governance was established here-the Regency and the Camera-and in 1738 the offices of the General Superintendent, the Royal Court, and the Consistory. The east and west wings were given to administration. The south wing was transformed into the arsenal, whereas the north wing preserved its religious function and held apartments for court needs. Of all the transformations, the changes to the south wing were the most controversial. The decorative late Gothic tops of the wing were replaced with a mansard roof, and the tracery decorations of the elevations were plastered (Figure 3a). The towers gained new Baroque finishing with royal initials. During the transformation, the cloister was demolished from the side of the large courtyard together with a Renaissance gate on the south side. The latter was replaced by panoplies based on pillars. Following the words of Krystyna Kroman- "Most probably, the bad condition of the tops and parts of the roof combined with different aesthetic values of patrons and builders contributed to the wings appearance of the simple, raw Frederic Baroque. The king's efforts to erase traces of Pomeranian separateness probably also played a role in this case" (Kroman 1992, p. 92). The transformation of this time also covered the museum wing. In the area of the mint courtyard, $4.5 \times 26.5 \mathrm{~m}$ avant-corps was created, designed in the spirit of Prussian Baroque, for the purpose of the stables and coach house of the garrison's commander (Figure 3b). In the words of Henryk Dziurla, "These transformations brought little benefit. They should actually be considered as losses" (Dziurla 1959, p. 75). Functional transformations were also conducted in the castle. Various economic and residential functions were established in the former museum wing, and in 1752 Frederick the Great created a mint there. In 1769-1840, duchess Elisabeth of Brunswick - the divorced wife of the Prussian duke - resided in the apartments of the west wing.

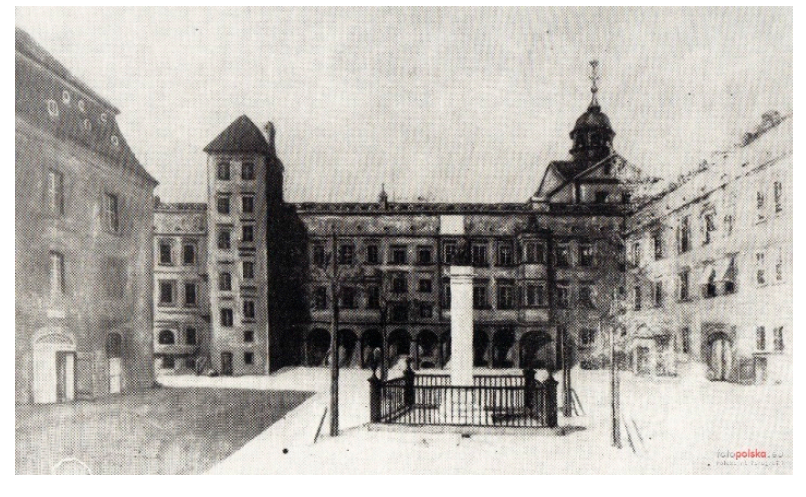

(a)

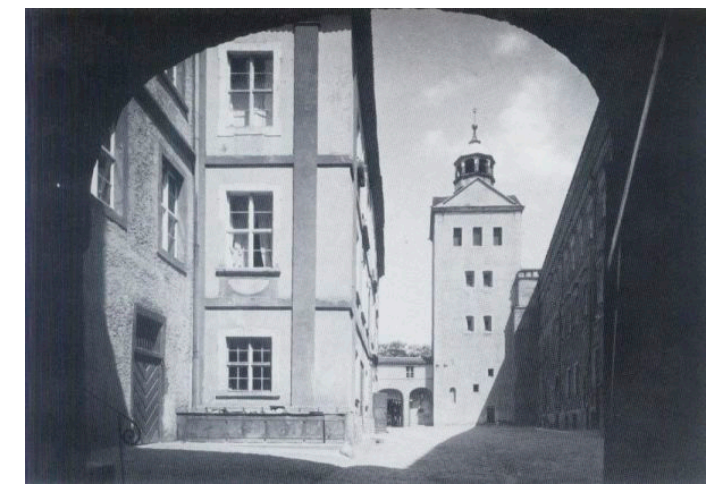

(b)

Figure 3. (a) The main courtyard of the castle after the reconstruction of the southern wing (left) and the demolition of the cloisters in the northern wing, source: fotopolska.eu; (b) mint courtyard and a view of the new avant-corps in the museum wing, source: sedina.pl. 
In terms of the appearance of the castle, less beneficial transformations were introduced in the 19th century. At that time, the works resulted mainly from the growing need for offices for the many government bodies established in the castle. The government employees constantly lacked office space and places that would serve them as archives. In the 1820s, a gable roof was added to the east corner of the north wing, and the north cloister of the large courtyard was dismantled due to its bad technical state. In 1832, the east wing vaults were demolished to the ground level and a new division of rooms was introduced. The ground floor and the second floor became the office space, whereas the first floor featured apartments of the President of the Province of Pomerania. In 1733, a summer pavilion was added outside of the north wing. In 1840, king Frederick William IV agreed to the proposed transformation and expansion of the north and west wings. The works began in 1842. In the north wing, the wall of the attic was removed and replaced throughout its entire length by a fourth floor established as an archive (Figure 4a). In the north-east corner, a polygonal neo-Gothic observation tower topped with battlements was constructed, and a loggia with a staircase was built in the central part of this wing (Figure 4b). The forms of new elements featured Classicist and neo-Gothic detailing, referring to Romantic architecture (Kroman 1992, p. 95). The designer of the new elements was Karl Friedrich Schinkel, who created his design based on the idea of duke Frederic William (Gwiazdowska 2006, p. 16).

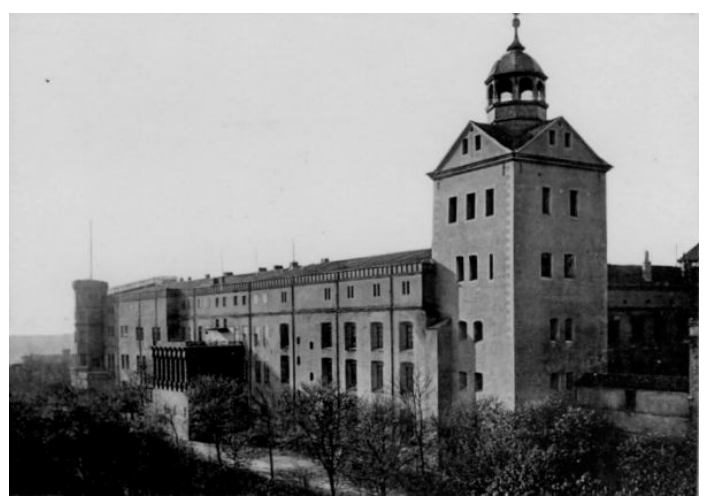

(a)

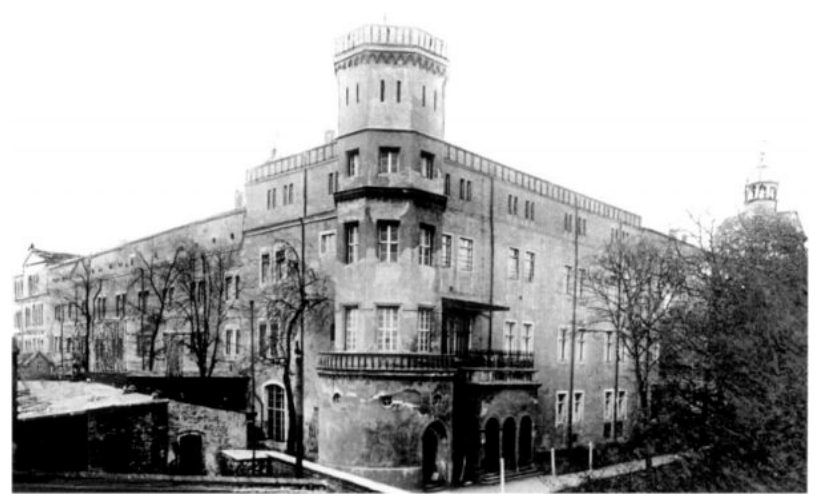

(b)

Figure 4. (a) Northern wing after expansion, source: sedina.pl; (b) Neo-Gothic tower on the northeast corner, source: sedina.pl.

Many parts of the west wing were demolished and some of the interiors were functionally transformed to become office spaces. The cloister on the west side of the wing was also demolished. The transformation resulted in a new appearance of the wings from the side of the courtyard-they became more ascetic with a barracks-like character, which was very different from the previous Renaissance design (Kroman 1992, p. 98) (Figure 5a). In 1862, the castle chapel was transformed, and in 1872-1874 the south wing was dismantled to ground-level perimeter walls. A new structure was placed in that area, with remarkably simplified elevations and additional rooms for administrative purposes (Figure 5b). The Regency's construction counselor-Homann-tried to save the valuable medieval wing with the Renaissance wooden ceiling in the ground floor hall. He proposed to renovate the interior and establish a court dining hall. The arguments presented by the counselor, and his propositions were not supported by king Frederic William IV. Eventually, a new level was built to preserve the ceiling. It was used to present art collections. Despite the preservation of both original towers during the transformation, the brick staircase in the clock tower was replaced by an iron one. From the southern side, the wing also received an avant-corps with a staircase. 


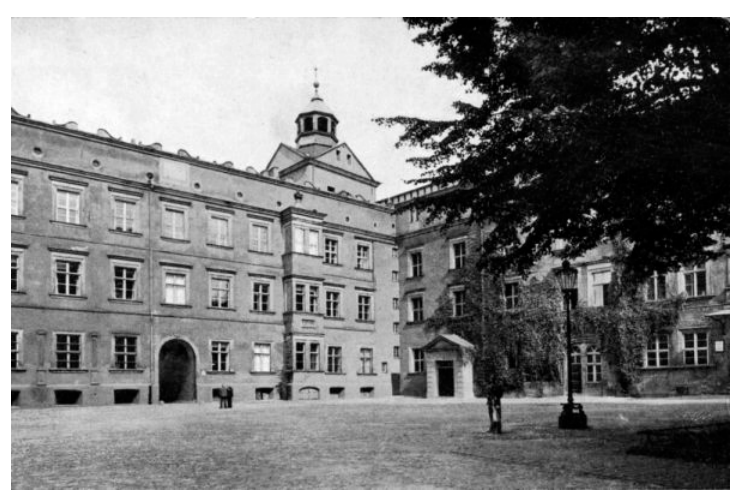

(a)

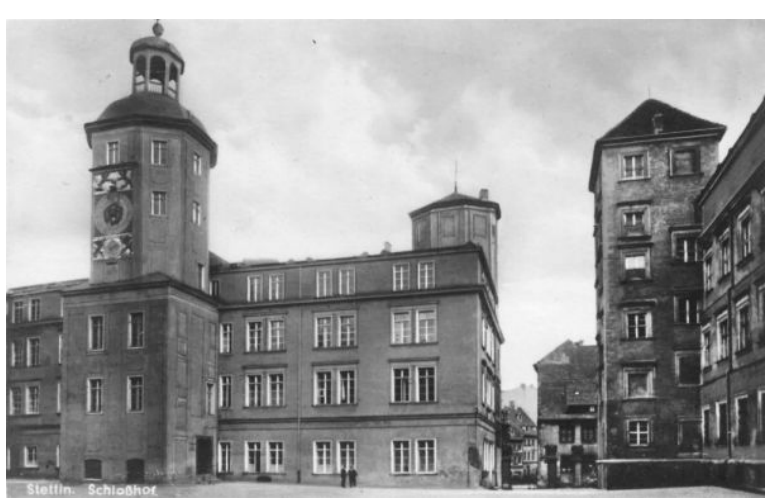

(b)

Figure 5. (a) Main courtyard after cloister demolition, source: sedina.pl; (b) the southern wing after second reconstruction, source: sedina.pl.

The 20th century did not bring many changes in the established form of the castle. The seats of numerous government offices whose needs contributed to the significant degradation of the structure gradually became more empty. These institutions were moved to the newly constructed, representative buildings in other parts of the city. This situation led to the first, modest renovation and conservation, as well as the rediscovery of the lost historical and artistic value of this precious monument. In 1926, the mistakes of former years were noted down by Franz H. Viergutz, a historian who stated that it would be good to restore the past glory of the castle (Kroman 1992, p. 101). The castle was destroyed during the Allied bombardment of the city on 17 August 1944. The only remains were the external walls, whereas the rest of the structure burned down.

\subsubsection{The Attitude of Polish Authorities towards the Castle and Its Reconstruction after 1945}

The enormous damage inflicted upon Szczecin during World War II virtually erased the old town area from the map and led to the destruction of the oldest and most valuable monuments (Figure 6a). As a result of valorization, the post-war conservators selected only 18 monuments of medieval or modern origin (Fiuk 2017, p. 123; Gwiazdowska 2016, p. 185). Nineteenth century buildings that had been destroyed were considered worthless, culturally alien, and not deserving reconstruction. When considering which buildings to restore, the argument of national origin was frequently used to highlight the importance of structures that proved the Slavic origin of the city (Gwiazdowska 2016, p. 186). The search for Slavic themes and the elements of Polish culture in monuments also determined the form of the architectural restoration. The castle-which was considered as the former seat of the Griffin dynasty, the Slavic rulers of Pomerania-was among monuments scheduled for restoration (Dziurla 2008, p. 75). The reconstruction of the castle became a symbol both for the political authorities of that time as well as the conservators. 


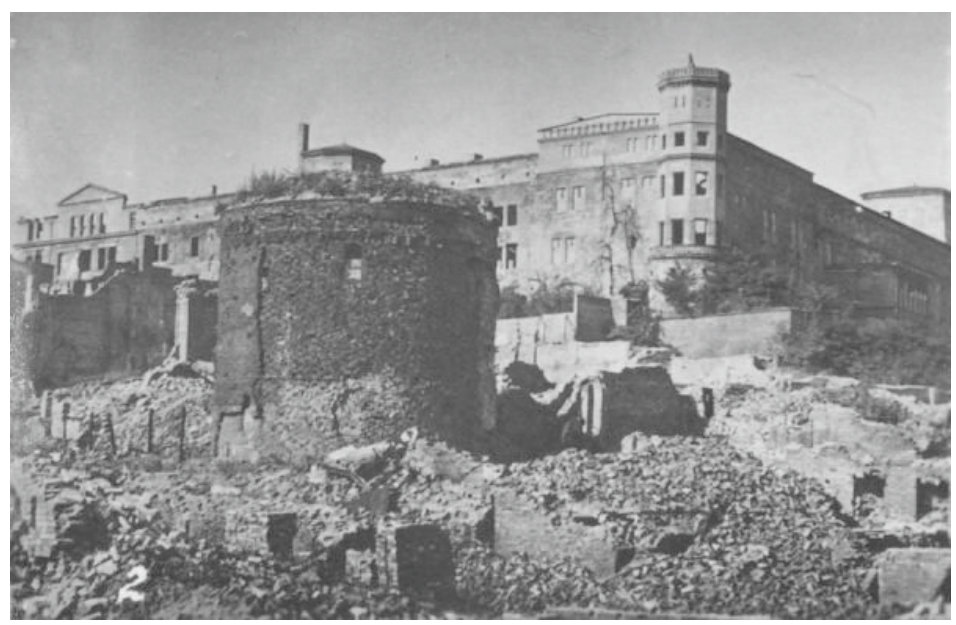

(a)

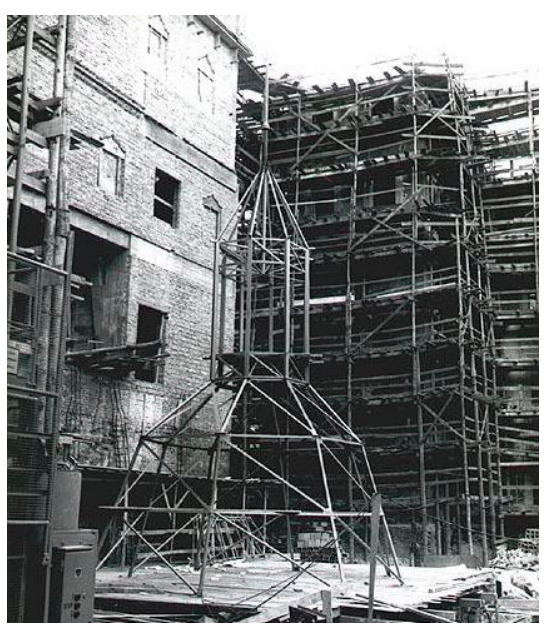

(b)

Figure 6. (a) The castle after the war damage, source: sedina.pl; (b) reconstruction of the south wing, source: sedina.pl.

The reconstruction started with necessary inventory works, followed by unavoidable demolitions and strengthening of the structure. At the same time, the first restoration concept designs were made in parallel to archeological studies (1848-1854). Preserved archived documents were analyzed in terms of the previous form of the structure. In the 1950s, the community of conservators held a number of discussions and arguments regarding the final form of the reconstruction. The reconstruction of the most damaged south wing was particularly controversial (Nekanda-Trepka 2008, pp. 99-112). Eventually, the return to the pre-war and modernized neo-Gothic forms was rejected in favor of the original historical concept (Figure 6b).

The main recommendation for the entire structure was to restore its representative character, established near the end of the reign of the ducal dynasty. The reconstruction of the castle began after the decision of the Presidium of the Provincial National Council in 1958. It started from the least damaged north wing. The design was developed by a Szczecin design office-PP PKZ-led by Professor Stanisław Latour. The first step was to remove the unoriginal 19th century. elements that survived the war. During the course of the activities, the additional storey, the octagonal tower, and the loggia were removed. The Renaissance attics of the wing were restored together with the cloister on the side of the courtyard, and the vaults were reconstructed in their original forms. After the work was finished, a concert hall was established in the former chapel, and the former residential interiors were transformed into exhibition halls. In 1973, a decision was made regarding the final form of the reconstruction of the south and west wings, and their purpose was determined. A discovery made the same year by Zbigniew Radacki in the Swedish archives influenced the decision regarding the design of the south wing elevation. Discovered drawings from 1673 by Jan Joachim Zeuner showing the castle in its late Gothic and early Renaissance forms constituted convincing iconographic material that allowed for a relatively faithful reconstruction of the original tracery tops of this wing (Figure 7a,b). The newly acquired images were collated with previous representations and architectural analyses of the wing continued. This provided a solid basis for the development of a detailed design. The remains of the walls of the wing-which dated back to the 19th century-were demolished to ground level and replaced by the reconstructed, late Gothic wing, which was connected to the west wing using a modern connector. The structure's form followed the arrangement at the time of the Pomeranian Dukes. New tented roofs with Renaissance forms were built atop castle towers, the cloisters and attics were restored in east and west wings, and the modest Baroque form of the mint wing was reconstructed. The works finished in 1978, and a music theatre took over east, south, and west wings. Office space was established in parts of the east wing and in the mint wing (Figure $8 a, b$ ). 


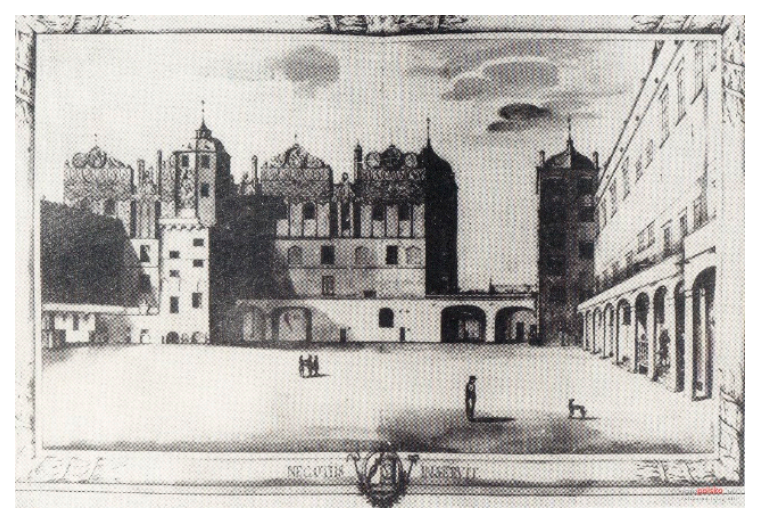

(a)

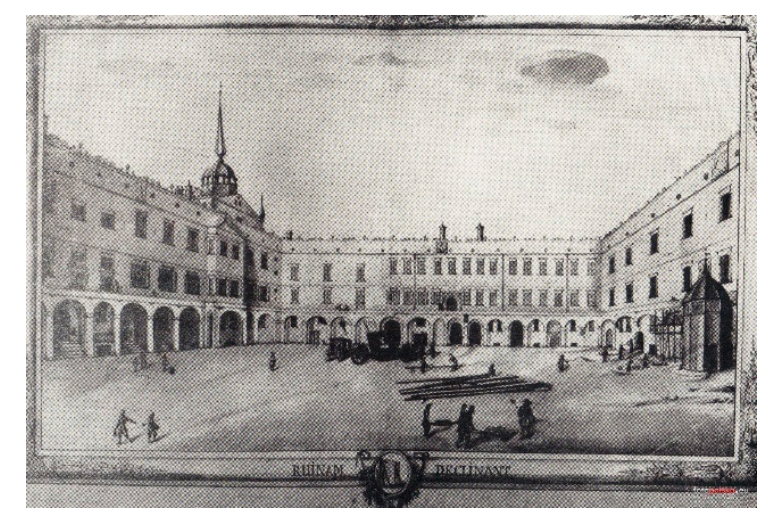

(b)

Figure 7. (a) Jan Joachim Zeuner, main courtyard in 1673, source: fotopolska.eu; (b) Jan Joachim Zeuner, main courtyard in 1673, source: fotopolska.eu.

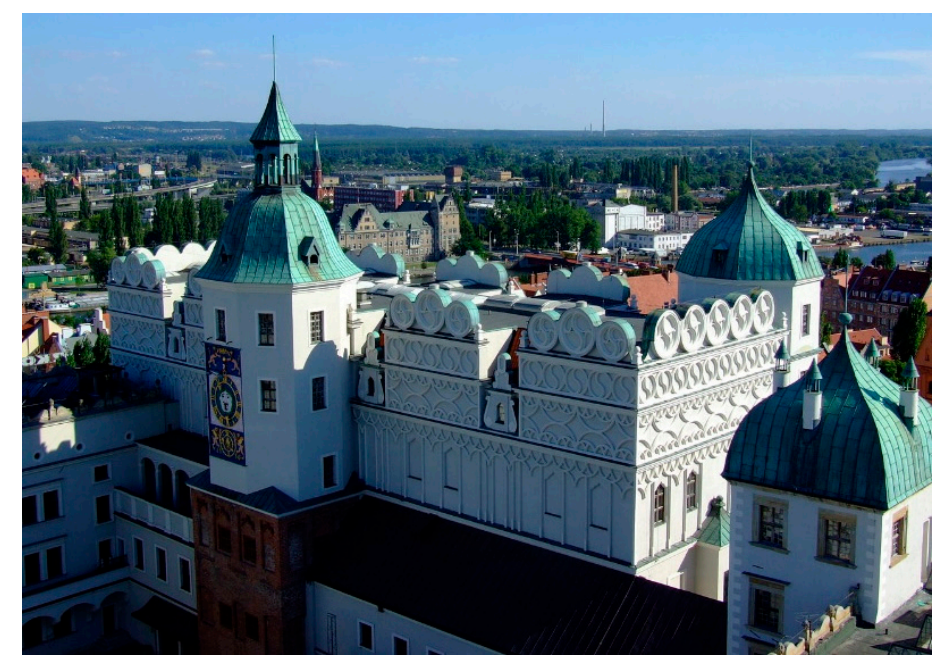

(a)

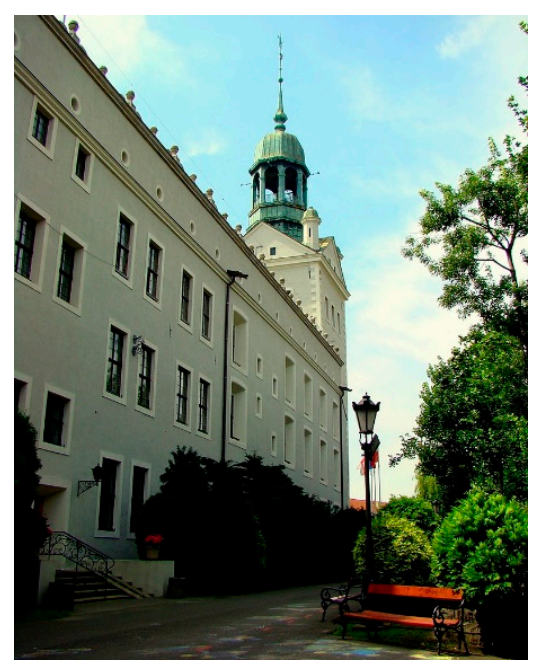

(b)

Figure 8. (a) The current shape of the south wing, public domain; (b) the current shape of the north wing, photo: Mateusz War., source: Wikimedia Commons.

\subsection{The Case Study of the Ducal Residence in Stupsk}

\subsubsection{The Historical Background of the Creation of the Ducal Residence in Słupsk}

The Sławno-Słupsk area was annexed by Poland in 1119. In the 12th century, the area of Słupsk belonged to the Sławno-Słupsk Duchy. In the second half of the 12th century, Ratiborides originating from local tribal rulers governed in the Duchy. Around 1210, Danish king Valdemar II conquered this part of Pomerania, but in 1217 duke Świętopełk of the dukes of Gdańsk reclaimed the land. During his rule, Świętopełk made a very important political decision that connected this land with Poland. He transferred the diocese jurisdiction to the archbishopric of Gniezno. At the time, the first ducal residence in Stupsk was a gord located on the right side of the main course of the Stupia river (the first information about the gord dates back to 1248). In 1282 in Kepno, Mestwin-the Duke of Gdańsk-made a pact with Przemysł II, the duke of Greater Poland. On the basis of this pact, Przemysł gained the inheritance of all of Mestwin's wealth. Five years later in Słupsk, there was a meeting of three dukes: Mestwin II, Przemysł II, and Bogislaw IV—-the duke of West Pomerania. The dukes signed a treaty of unity and peace, which was a manifest against the partitioning tendencies of the neighboring Brandenburg. After the death of Mestwin in 1294, Przemysł took over his duchy and one year later he also became the king of Poland. His tragic death in 1296 made Władysław Łokietek 
the successor of this part of Pomerania. As a result of the treason of the rich Święc family in 1307, the land of Słupsk was taken over by the Brandenburg margraves Waldemar and John. To strengthen their power, they colonized Słupsk in 1310 on the basis of the Lübeck law. However, the rule of the Brandenburg over the area of Słupsk did not last long. In 1317, Słupsk was taken over by duke Wartislaw IV of the Griffin dynasty, who united the entire Pomerania under the rule of his own dynasty. This way, the second rule of the Griffins over this part of Pomerania began, which was associated with the formation of a new ducal residence in Słupsk, within the ducal domain located in the southern part of the city near the mill and the Dominican monastery.

\subsubsection{The Ducal Castle in Słupsk during the Rule of the Griffin Dynasty}

The first attempt to erect a castle was made in 1339 by duke Bogislaw V. His son Casimir continued his effort, however unsuccessfully. Another attempt to build a castle was made by Bogislaw VIII, who managed to finish one level of the fortress. However, the construction worried the townspeople of Słupsk, who thought that the project would strengthen the duke's rule over the city. In exchange for a loan, the townspeople managed to persuade the duke to stop the construction. The duke agreed to construct only the court. Eventually, Bogislaw X built the castle in 1505-1507. The structure had a rectangular $16.5 \mathrm{~m} \times 35 \mathrm{~m}$ envelope, with an octagonal tower added on the north-west side. The construction of the building used fragments of earlier structures dating back to the times of Bogislaw V and VIII. From the north side, the building was adjacent to defense walls of the city, so it was situated in the former moat. It was a building with a basement, with two levels above the ground. The castle was erected using erratic boulders and bricks, giving it a late Gothic style. At the time, the fortress had a defensive and residential function. In 1580-1587, duke John Frederick decided to transform the castle into a residence for his wife, Duchess Erdmuthe. The design and supervision were handed over to the architect Wilhelm Zacharias. The transformation was supposed to give the castle the form of a Renaissance ducal residence. The construction works began by disassembling the upper floor in order to build two new levels. A loggia was added to the elevation on the east side of the tower, as well as two small avant-corpses from the south, and bay windows in the west and east elevations. The elevations were plastered highlighting the corners with bossage. The entire structure was covered with a hipped roof. Vaults and ceiling were placed inside the castle, while a staircase was built inside the tower. The castle interiors received a rich decor. A report prepared in 1682 by captain von Podewils stated that the castle complex included 7 buildings (main building, kitchen building, mast, covered passage to the church, "new room" at the gate, office building, and new house). The main building consisted of 89 rooms, including four great halls with a representative knight hall on the second floor. The castle was richly equipped. The chamber of the duchess featured a fireplace made of black and red marble, a black and white marble floor, and walls upholstered with white satin and decorated with black figurines. Works of art included tapestries, paintings, arts and crafts elements, as well as a valuable collection of books. The end of the glorious days of the castle came in 1684 with the death of Ernst Bogislaw von Croÿ, the last duke of the Griffins of Słupsk. At that moment, the castle and everything in it became the property of the Brandenburg.

\subsubsection{The Attitude of Brandenburg, Prussian, and German Authorities towards the Castle until 1945}

After the death of duke Ernst Bogislaw von Crö̈, most of the precious movable equipment was given to his heirs. Following the order of Frederick William I of Prussia in 1731, the remaining equipment and interior decor were dismantled, moved to Berlin and — to a large extent-sold at an auction. Zdzisław Machura wrote: "It seems that the attitude of authorities aimed at erasing the memory about Pomeranians from everything that was connected to the Griffin dynasty. For this reason, the castle in Słupsk —as one of the symbols of this family's rule-was brought to such a state" (Machura 2004, p. 63). The auctioned items included portraits of Barnim I, Bogislaw X, and his wife Anna Jagiellon and Ernst Bogislaw von Croÿ. All of the portraits were sold for a symbolic (at that time) price of about 5 thalers. Taking into account how invaluable these works of art were for the 
history of Pomerania, the intentions of the Prussian ruler were clear. In 1815-1821, the castle was devastated entirely as a result of the transformation. After lightning damaged the tower of the castle in 1815, Prussian authorities decided to demolish the tower to the level of the main body of the structure, and to cover the building with a shed roof (Figure 9). In 1821, the castle was given the role of a military warehouse. Ceilings and roofs were demolished and an additional low storey was added. The number of levels inside the structure increased, and two new wooden ceilings were built, supported by wooden pillars. Moreover, the window openings were bricked up and made smaller. In 1866, the remaining utility buildings were disassembled. Previously, they formed the castle complex around the main courtyard. Before the outbreak of World War II, the building served as a warehouse for theater decorations, and its technical state had been steadily deteriorating, which did not add any glory to the city. In the 1920s, there was a debate about using the castle for cultural and museum purposes. At that time, plans and drawings of the castle and its surroundings were prepared, showing further transformation of its original shape and context. The plans were reviewed in the 1930s, but they were not implemented before the war. In 1939, only minor repairs were made for the buttresses on the south side. The behavior of Brandenburg Margraves, Prussian kings, and then German authorities indicated a well-defined policy towards the heritage of the Pomeranian Dukes. The policy aimed at erasing the image of the castle as a ducal residence, acknowledging only its utility role. The castle was stripped of any representative attributes, and valuable equipment disappeared. As Zdzisław Machura points out: "The castle went through all kinds of times, from richness and splendor to ruin brought upon by Prussia and Brandenburg, the political adversaries of the first rulers of the castle" (Machura 2004, p. 7).

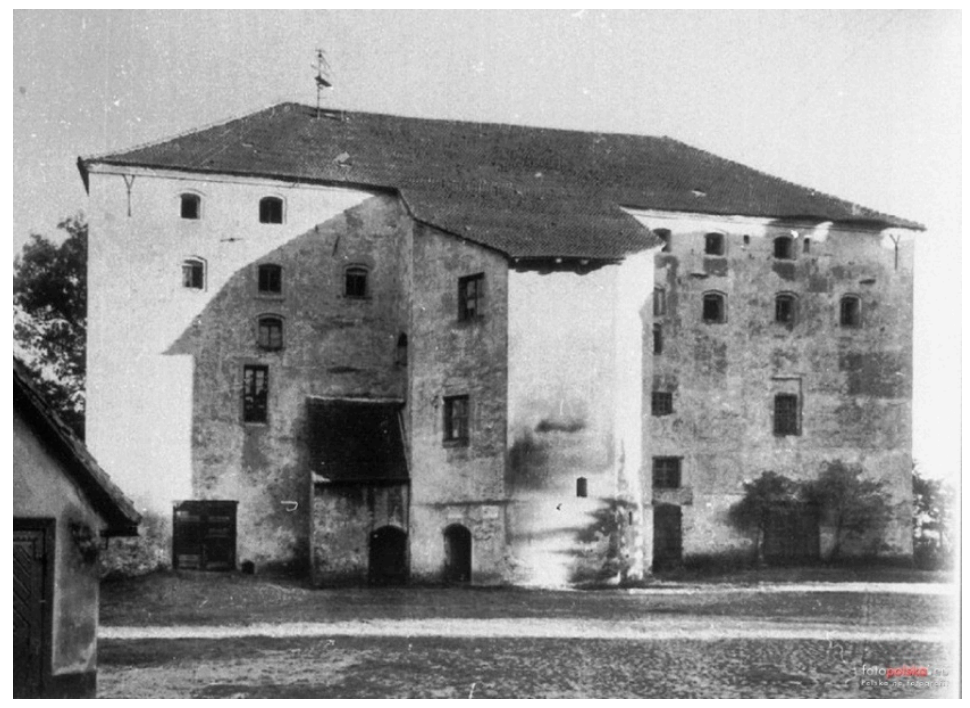

Figure 9. The Pomeranian Dukes' Castle in the interwar period, source: fotopolska.eu.

\subsubsection{The Attitude of the Polish Authorities towards the Castle after 1945}

The castle was destroyed in 1945, but the perimeter walls of the main body and the tower survived. In 1947, the castle was secured by placing a temporary roof over the walls. One year later, it was leased to the West Pomeranian rope and mesh factory to prevent the further deterioration of the place. In 1958, following the initiative of Maria Zaborowska, the head of the Municipal Museum in Słupsk; Jan Stepień, the head of the Municipal National Council; and Feliks Ptaszyński, the Voivodeship Conservator of Monuments, funds were raised to reconstruct the castle with the intention to create the headquarters of the Regional Museum. In 1959, Adam Stefanowicz developed the initial architectural reconstruction design for the castle's shell and the interiors and land around it. Despite the radical change in function, the adaptation design preserved the historical division of rooms into five transverse bays. The reconstruction was completed in 1965, restoring the building to its Renaissance character 
dating back to the times of the Pomeranian Dukes (Figure 10). During the reconstruction, an attempt was made to save a few original construction elements, such as parts of the ceiling or window recesses, as well as the elements of architectural detail, such as profiled window frames. Unfortunately, only two vaulted rooms on the ground floor and the spiral staircase of the tower-so characteristic of ducal castle architecture-survived from the original arrangement. Architectural site studies helped to recreate the original arrangement of Renaissance window openings and determine the location and dimensions of the former Knight hall with the orchestra balcony and the basket vault. The reconstruction adjusted the remaining rooms to cater for the modern museum, and an additional staircase was built. In the museum hall on the ground floor, architects exposed a fragment of the original wall with its monk bonding method, which was supposed to confirm the Slavic origins of the building.

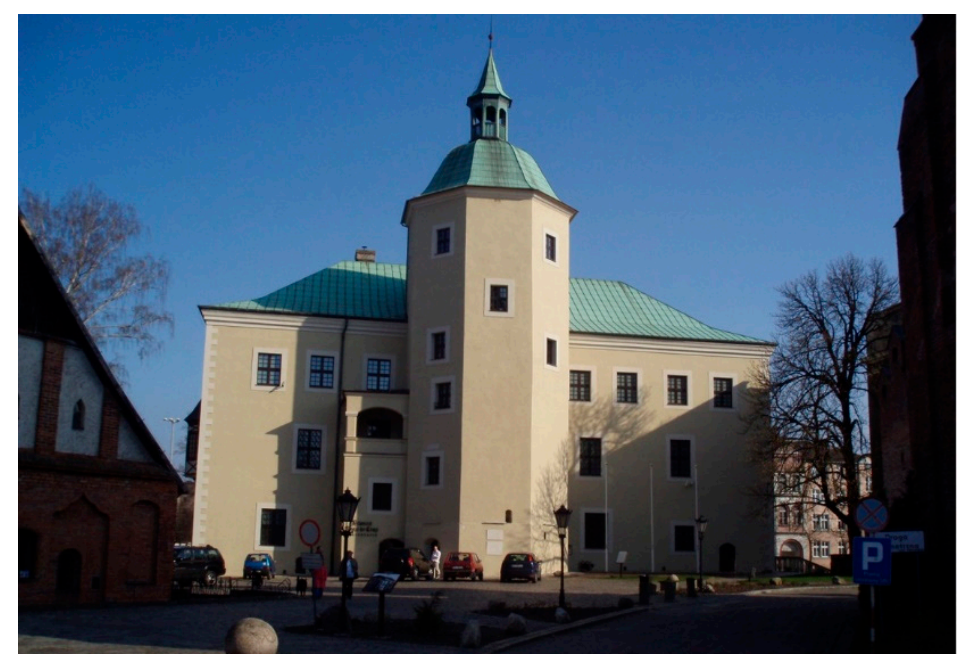

Figure 10. The Pomeranian Dukes' Castle after the postwar reconstruction, National Heritage Board of Poland, source: Wikimedia Commons.

When it comes to the form of the exterior, the most important intervention was the reconstruction of the tower together with the Renaissance cupola, and the reconstruction of the loggia and bay windows in the elevation. In subsequent years, renovation focused on the immediate surroundings of the castle with the reconstruction of the old mill (1965-1968) and the manor (1972-1979), as well as renovation and adaptation of the mill gate, which was finished in 1979. An important moment was the transfer of the sarcophagi and clothes of duchess Anna von Croÿ and duke Ernst Bogislaw von Croÿ to the Museum of Central Pomerania in 1982. The artefacts enriched the regional collection after the many years of conservation. The post-war reconstruction of the castle and the new function for the building indicate the different attitude of Polish authorities towards the heritage of the Griffins, one that is a stark contrast to the approach of the German authorities. The essence of the reconstruction was to restore the form of the ducal residence and set up an important center of remembrance of the Griffin dynasty, a dynasty which once ruled in Słupsk. Though the intention behind the reconstruction may not be as vivid as in the case of the Pomeranian Dukes Castle in Szczecin, the idea seems obvious. Similarly to the authorities of Szczecin, the local government of Słupsk wanted to highlight the Slavic and native origins of the land by reconstructing the symbol of ducal power. The castle was to become a solid proof that this land belonged to a "Slavic" dynasty. This should confirm the rightful rule over these territories in the new political reality - the reality of Poland which "extended" westward after World War II. 


\subsection{The Case Study of the Ducal Castle in Darłowo}

\subsubsection{The Ducal Castle in Darłowo during the Times of the Griffin Dynasty}

The Darłowo castle is one of the seven castles funded by the Griffins in Pomerania. The remaining ducal residences were adapted or temporarily taken over by the ruling dynasty. The castle dates back to the 2nd half of the 14th century, the reign of Bogislaw V, who purchased the mill island in Darłowo. The envelope of the castle was rectangular $(32 \mathrm{~m} \times 34 \mathrm{~m})$. The windowless perimeter walls were erected to the height of $15 \mathrm{~m}$ (Nekanda-Trepka 1990, pp. 63-74). The tower in front of the walls included an entrance gate. Ground-level residential and utility buildings with basements were constructed on the south-west side of the gate tower inside the curtail walls, in the south-east corner and in the north corner. At that time, the castle was mainly used for defense. During the reign of Bogislaw VIII (and probably after 1403), the castle expanded, and the east wing was erected and set to become the ducal knight hall covered by a stellar vault (Nekanda-Trepka 1990, pp. 63-74; Radacki 1976, pp. 87-104). In 1449, duke Eric started residing in the castle and strengthened the defensive capability of the fortress, but the only thorough transformation featured the addition of a modest west wing. Around 1538, the castle was modernized using late Gothic forms and the east and south-east wings were expanded. At that time, the west wing-which was erected by Eric and which greatly narrowed the courtyard-was demolished. In subsequent years, a new wing was erected on the outer side of the west perimeter wall, the southern forgate was transformed, and a new north gate was constructed on the side of the city. Most probably, the castle deteriorated during the Thirty Years' War. However, near the end of the Duchy of Pomerania, the castle underwent some minor modernization and transformation.

\subsubsection{The Attitude of Prussian and Polish Authorities towards the Castle}

After the fall of the Duchy, the castle in Darłowo became the property of the Prussian domain and played a commercial role. It also served as a prison and a court. At the end of the 18th century, the west wing was deserted and began to deteriorate. The technical state of the entire castle gradually deteriorated. In 1833, a decision was made to dismantle the west wing to the ground, and a prison yard was set up. Partial transformation and demolishing affected the east wing. King Frederick William IV halted the final demolishing of the castle. The better years for the castle did not come until the 1920s (Figure 11). In 1925, the regional museum was organized there. However, the 1934-1935 restoration is still controversial today, as it was not based on any architectural studies.

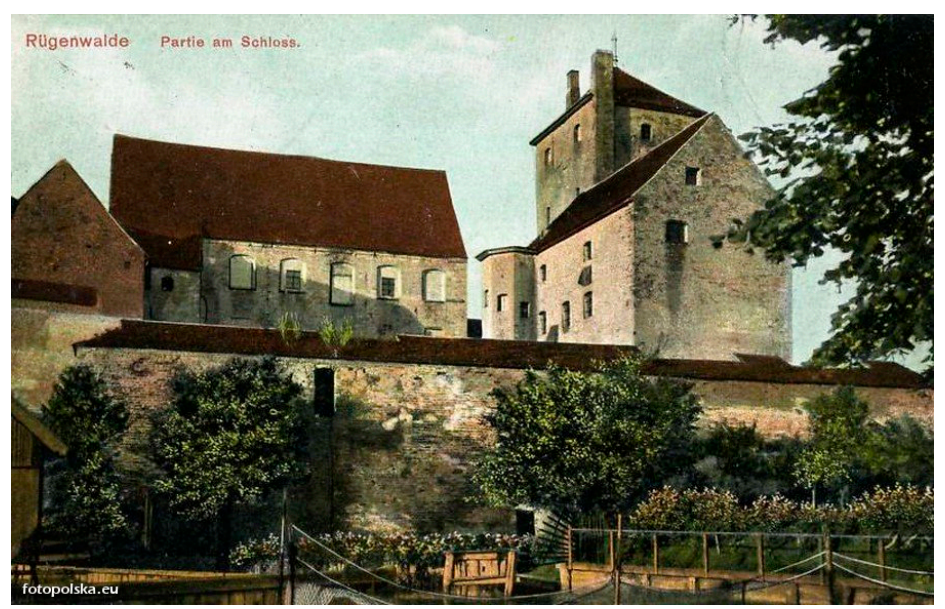

Figure 11. The Pomeranian Dukes' Castle in Darłowo in the interwar period, source: fotopolska.eu.

The castle survived the war and after 1945 became the headquarters of the Polish regional museum. Polish conservators conducted archeological studies in 1958, 1961-1966, and 1971-1972. Architectural 
studies were conducted in the years 1982-1985. Design and construction works associated with the post-war restoration of the castle were supervised by Janusz Nekanda-Trepka. The activity of Polish conservators referring to the monument were based on in-depth analyses of historical sources and in situ architectural studies. The restoration and reconstruction efforts focused only on the fragments of the castle whose appearance was known (Figure 12). Unsuitable elements, added during works conducted in the 1930s, were removed. The restoration of the castle concentrated mainly on interiors. One of its most visible effects was the reconstruction of a stellar vault at the ground floor hall in the east wing. The transformation of the Darłowo castle was slightly different than in the case of those in Szczecin and Słupsk, mainly due to restoration works in the 1930s and the little damage inflicted upon the structure during World War II. However, it should be noted that in the initial period after the fall of the Duchy of Pomerania, the attitude of Prussian authorities towards the structure was no different than in the case of the other Griffin Dynasty castles. The transformation into a prison and the demolishing of parts of the building to develop a prison yard are proof of a very negligent treatment of the monument and the effort to erase its earlier importance. The technical and functional degradation nearly led to the total destruction of this valuable castle.

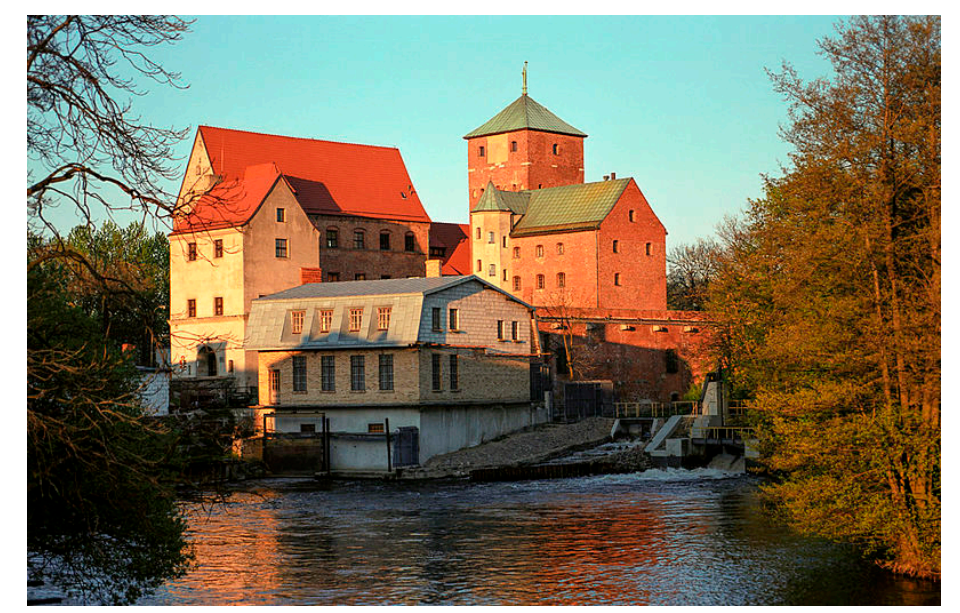

Figure 12. The Pomeranian Dukes' Castle in Darłowo today, photo: Jerzy Strzelecki, source: Wikimedia Commons.

\subsection{Transformations in the Case of the Remaining Ducal Residences}

Like the structures in Szczecin, Słupsk, and Darłowo, the remaining ducal residences in Pomerania underwent numerous transformations throughout the ages and were sometimes entirely destroyed. The destruction of the prominent residence in Wolgast-west of the Oder river-was largely due to the Brandenburg rule in 1675 . From that moment, the castle gradually deteriorated and was gradually demolished until the year 1843. The ducal residence in Grabowo near Szczecin (currently a district of the city) deteriorated largely due to the Swedish negligence. It was finally ruined and demolished completely in 1677. The majority of the castle in Ückemünde-which was entirely transformed around 1546 by the Wolgast duke Philip I into a representative seat in the late Gothic style-was demolished in 1720 following the order of the Prussian king. Only the south wing and the tower still remain today. It is worth to examine the history of two ducal castles on the east side of the Oder river. A small castle in Białogard (envelope of $20.5 \mathrm{~m} \times 11.5 \mathrm{~m}$ ) was erected at the site of a former early medieval gord by Wartislaw IV of Wolgast in 1315. Following the order of Frederic II in 1780, this castle was also demolished and replaced by a new structure to cater for the needs of the king's civic employees. The castle in Szczecinek was also subject to numerous transformations (Figure 13). After the takeover of the building by Brandenburg in 1650, the north wing was used as a warehouse, whereas the south wing was the seat of the town court. In subsequent years, the individual fragments of the structure were either demolished or redeveloped and the building had various functions. The structure was 
twice a prison and a granary; a corset manufacturing plant; a social care and work facility; a hospital; and, finally, an employment office. The structure was not badly damaged during World War II. After 1945, it was turned into barracks and, after the appropriate adaptation, it was an administration unit, a school, and a hotel. The examples above show the determined policy of Prussian authorities towards the ducal castles. They were often adapted to fulfill functions that were hardly representative-e.g., prisons or warehouses-or they were associated with the new rule, such as courts and civic offices. Unfortunately, when a structure was in a bad technical state or when it was impossible to adapt it to a new function, it was demolished and replaced with a new building.

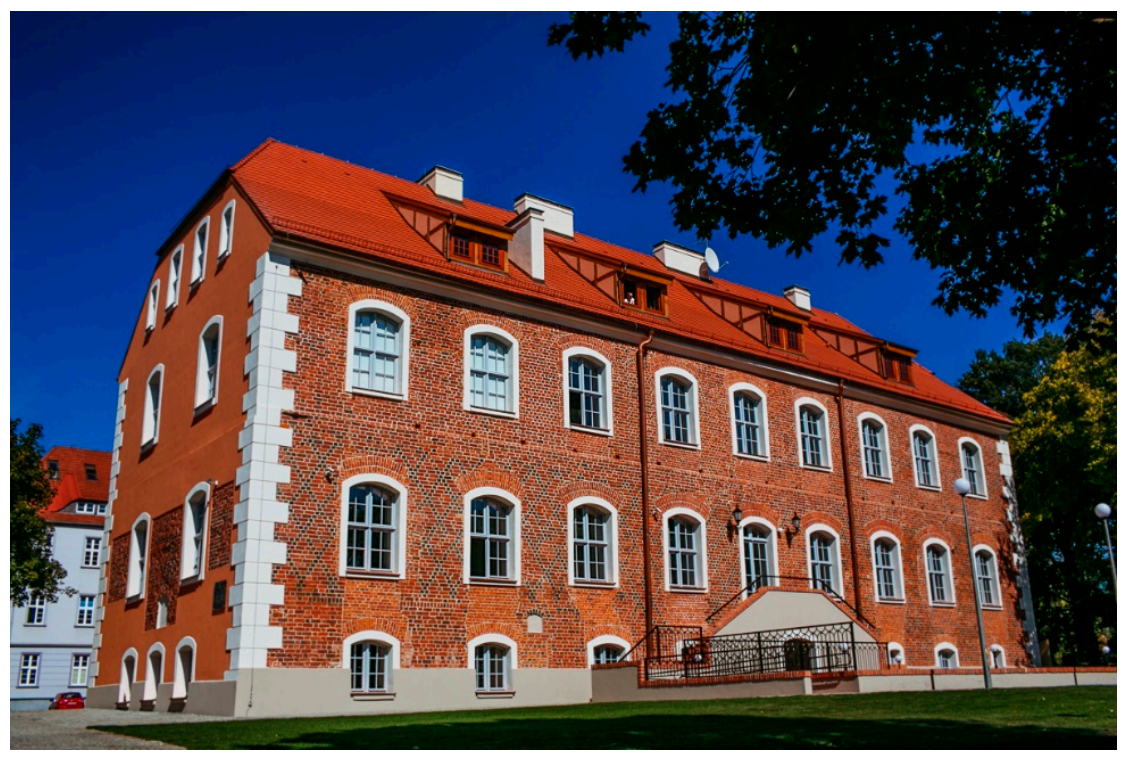

Figure 13. The Pomeranian Dukes' Castle in Szczecinek, source: Wikimedia Commons.

\section{Discussion}

\subsection{An Attempt to Evaluate Attitude of the Prussian Authorities to the Material Heritage of Pomeranian Dukes}

Transformations of and damage to the castles of Pomeranian dukes by Prussian and German authorities do not provide us with a full answer regarding the extent to which these activities were deliberate, resulting from the ambivalent attitude of the authorities, or whether they were caused by the social and economic situation of that time. Although all of these factors contributed to the scale of the degradation of ducal residences in Pomerania, the impact of the individual factors differed in various periods and regions of the former duchy. The analysis of the scale of the transformation and destruction gives us a broader perspective of the processes than an analysis of a single case. One of the factors that contributed the degradation of ducal castle architecture was the collapse of the then administrative system. The Pomeranian Duchy underwent numerous divisions into districts resulting in an increased number of ducal castles that served individual dukes. During the times when the duchy was united, the castles did not fulfill the role of a ducal residence and instead they served as administrative centers and were ready to accommodate the royal court if needed. At the time of the Swedish rule, some castles were still periodically used as royal residences (castles in Szczecin, Wolgast and Grabowo), while, during the Prussian times, only the castle in Szczecin fulfilled a residential role. At that point, other castles lost their main function. This is particularly true in the case of small provincial castles in Słupsk, Białogard, Szczecinek and Ückemünde. These fortresses were not needed anymore from the point of view of the royal court so they were either adapted to fulfill new functions or demolished. Recovered materials were used for different purposes. However, in this context, one cannot neglect the symbolic character of this type of actions, especially considering their scale and determination. The demolition of entire structures or their fragments, as well as the numerous 
transformations that aimed at erasing their former residential character undoubtedly contributed to the destruction of the memory about the independence of Pomerania which might have been the aim of the new rulers. In this symbolic context, the function assigned to ducal structures by the Prussian authorities is also not without significance. Many of these buildings were partially or entirely adapted to become warehouses, granaries, arsenals, prisons or-at best-civic offices and courts. Therefore, it can be stated that the choice was between an absolute functional degradation of a structure and the highlighting of the presence of the new rule in the area. ${ }^{1}$

An example that stands out in this context is the castle in Szczecin as the main ducal residence in the capital of Pomerania. While the abovementioned castles in Słupsk, Szczecinek, Białogard, and Ückemünde are examples of natural destruction, the transformation of the castle in Szczecin is a clear attempt to erase the character of the former ducal residence and give it some qualities of Prussian architecture of that time. In particular, the changes during the first phase of the transformation could have been motivated by ideological reasons. The transformation of the south wing in 1734 in the spirit of the Frederic Baroque and the establishment of the arsenal was most probably part of a plan to show the local populace that a new rule was present. Another aspect of these activities might have been the new residents' attempt to accommodate the castle space. In a broader context, it is worth highlighting that the transformation of the castle was a part of the bigger Prussian plan to transform the city. Firstly, a good example of the above is the construction of two new city gates, character of which referred to the triumphal arches erected during Baroque. These gates were the proof of the absolute power of the ruler and his sovereignty over the newly acquired Pomerania (Słomiński et al. 2000, p. 140). Despite the fact that the residential function of the castle officially remained, the king also decided to erect a new palace in Szczecin for himself. The building located at the Parades' White Square (new, representative urban space) was supposed to combine functions of a king's residence and headquarters of the Parliament of Pomeranian States. Both functions were moved from the castle. The hierarchy of new political relations was also expressed in the architecture of the building, which followed the Potsdam style. The frontage of the palace featured the Pomeranian coat of arms which was somewhat hidden under the balcony over the main entrance, whereas the king's coat of arms was put on the tympanum of the main avant-corps in a very exposed place. The external form of the structure combined the qualities of residential and military architecture. The aim was to remind the residents of the city about the absolute character of the new rule and the strength of its military (Słomiński et al. 2000, pp. 91-96; Gołębiewski 2008, pp. 141-42). Therefore, the construction of the palace was partially associated with the degradation of the role and the significance of Szczecin's castle. Suffice to say that even before the palace's construction, Frederic William did not stay at the former ducal residence, but used the hospitality of general von Borcke, the fortress commander (Słomiński et al. 2000, p. 91).

Therefore, the policy of Prussian authorities towards the ducal residence during the first stage of the rule consisted of numerous symbolic gestures that revealed their true intentions. This policy was clear from the very beginning, when the king accepted the tribute from Szczecin's townspeople in the castle courtyard in 1921. Other similar gestures with reference to the castle include the creation of an arsenal and the headquarters of main royal offices, the relocation of the Parliament of Pomeranian States, which used to be a symbol of Pomerania's independence. Moreover, the king placed royal monograms in the towers and removed ducal armor and banners from the castle chapel and transported them to Berlin. All of these activities manifested the attitude of the new ruler towards Pomerania during the initial lack of support to the new rule from the townspeople (Wiśniewski 1963). This was the manifestation of a colonial policy towards the conquered Pomerania region. According to Ewa

1 The issue was also raised by A. Bartetzky while referring to the reconstruction of the Malbork Castle, which was converted by the Prussian government into a granary and abandoned, despite the fact that it was a symbol of Germanic culture. Conrad Steinbrecht, the castle reconstruction manager, referred to the process as a functional degradation counterproductive for the "German cause" and contradictory to the German national interest (Bartetzky 2012). The activity driven by utility goals diminished existential and situational values. 
Rewers, this kind of policy helps justify nationalistic ambitions and strengthens hegemony of a single culture (Rewers 2005, p. 294). Undoubtedly, one of policy goals was to eliminate the previous local identity of Pomeranian citizens and impose a new Prussian one. The new identity was expressed through new social, political, and economic relations but also in the new shape of space.

A different evaluation would have to be made for the transformation of the castle in the 19th century. First of all, the changes were utility-driven and resulted from the necessity to solve accommodation problems or counteract technical wear of the individual parts of the building. However, in this period we can also highlight some symbolic activities that aimed at giving the castle a more German appearance. In this context, an example is the expansion of the north wing conducted using neo-Gothic and Classicist forms so characteristic of the national style present in Germany at that time. Another fact worth mentioning is that the bust of the Grand Elector Frederic William, who conquered the city in 1677, was placed in the castle courtyard in 1833 (Figure 14). The memorial was ordered by king Frederic William III. It was supposed to legitimize the rule of the dynasty of Hohenzollern over Szczecin and was to become a new patriotic accent (Gwiazdowska 2006, p. 16).

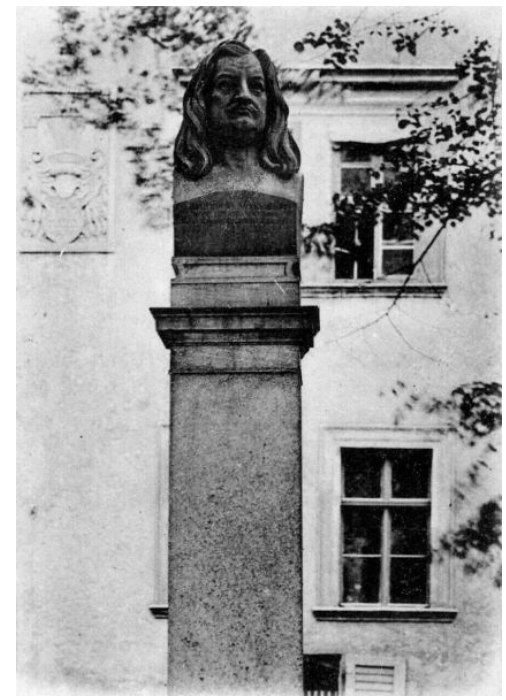

Figure 14. The bust of the Grand Elector Frederic William in the castle courtyard, source: sedina.pl.

To summarize, the Prussian and German rule over Pomerania brought either a negative or ambivalent attitude towards the preserved heritage of Pomeranian dukes and contributed to the significant decrease in the number of ducal residences, as well as to deterioration of their aesthetic and functional value. The fact was also recognized before the outbreak of World War II by German local government and conservators, who began an initial restoration of the castles in Szczecin and Darłowo.

\subsection{An Attempt to Evaluate Activity by Polish Authorities with Reference to the Material Heritage of Pomeranian Dukes}

The attitude of Polish authorities regarding the preserved heritage of Pomeranian Dukes was completely different to the actions of the Prussian and German rulers. In contrast to the previous hosts of these lands, Poles wanted to expose the ducal past of the castles built by the Slavic dynasty, a dynasty which was inaccurately referred to as the Piast dynasty (Piskorski 1946) ${ }^{2}$. Ducal residences-restored to their original state-were expected to prove the ethnic past of these lands, their association with Poland, and the "historical justice" — the idea that Pomerania returned to its origins after several

2 Although the family link between the first Griffins and the Polish Piast dynasty has never been proven, the Pomeranian dynasty was described as having a direct connection with the dynasty of the first Polish kings. It was a part of propaganda designed to reassure Poles displaced to Pomerania about the Polish roots of the ducal dynasty. 
hundred years of unjust Germanization (Zachwatowicz 1948, pp. 244-54). Although the attitude of Polish and German authorities towards the heritage of the Griffins differed, their actions were based on the same intentions. For Prussia, it was important to erase the ducal past of the Szczecin's castle, whereas for Poland the basis for further activities was to eradicate Prussian past. This resulted in the lack of acceptance of the parts of the castle that were preserved from this period. In both instances, it was an attempt to mark and accommodate the ducal heritage which, on its takeover, had negative connotations.

The important objective conditions that differentiate the context for German and Polish activities include the different degrees of degradation and conservation ideology in both periods. It should be pointed out that the restoration of the ducal form of residences in Szczecin and Słupsk depended on the enormous scale of their destruction. Nowadays, it is difficult to speculate on how these transformations would have progressed, provided the monuments had survived the war without any damage. Polish conservators often highlighted that the damage inflicted upon monuments during wars open up space to remove neo-historical and worthless 19th century layers and promote the "extraction of their most valuable artistic qualities" (Zachwatowicz 1965, p. 46). Therefore, political intentions conform to the post-war conservation doctrine, which is clear in the statements by conservators who based their opinions on both substantial and ideological grounds (Dziurla 1959, pp. 91-97; Latour 2008, pp. 51-72; Zachwatowicz 1948, pp. 244-54). Jan Zachwatowicz - the lead national conservator wrote that, in the face of the enormous wartime destruction, conservation supported the preservation of the original appearance of the castles, whereas their later transformations lose their significance when compared with the necessity to present the society with a complete image of the destroyed culture. In this context, the reconstruction of ducal castles in Szczecin and Słupsk in their original forms seems to be a natural course of action.

These objective factors were also accompanied by political and symbolic intentions. Piotr Zaremba, the first president of Szczecin, frequently highlighted the significance of the reconstructed Castle of Pomeranian Dukes for the acknowledgment of Polish rule in Pomerania (Zaremba and Orlińska 1965, p. 96). At the same time, spatial development aimed to create a proper exposition and a dignified site for the castle in the city's panorama (Gołebiewski 2018, p. 213). Thanks to these efforts, it could become a proper counterbalance for civic buildings on the Hakenterasse embankment overlooking the river, buildings which were erected in the spirit of the William's German architecture. The determination of political and conservation authorities of that time aimed at the restoration of the dignity of the castle in the city space and of the appropriate form related to the Polish cultural circle-resulting largely from the eagerness to create a spatial symbol of the "roots" for the immigrant population that came to the post-German city (Ochendowska-Grzelak 2018, pp. 2-6; Latour 2008, p. 66). The sole separation from the pre-war form manifested the rejection of the German cultural heritage and its replacement with the Polish one (Fiuk 2017, pp. 63-64). Therefore, the reconstruction of the castle in its late Gothic and Renaissance forms was a symbolic colonization and the adaptation of the post-German city (Musekamp 2013, p. 160; Praczyk 2015, pp. 125-26). Thus, the castle, which embodied artistic, material, and symbolic values characteristic of the Polish culture, was to promote the identification and integration of the new community with a foreign territory (Wallis 1990, pp. 13-16).

Although these activities were overt and clear mostly in Szczecin, they should also be noticed with reference to the remaining ducal castles in West Pomerania. The reconstruction of the castle in Słupsk as well as the conservation of castles in Darłowo and Szczecinek were a product of the same process. It is also worth mentioning that, apart from the castle in Szczecinek, all other restored castles were converted into museums presenting the history of the Duchy of Pomerania and the Pomeranian dynasty. The ducal castles became both a material and living (due to their educational role) monument of the Griffin dynasty and began to fulfill the role of old border stones that marked the land as a part of Poland. Importantly, the narration created after the war remains valid today, despite the political transformation of 1989, and the ducal buildings today are an important part of the local identity of West Pomerania residents. 


\section{Conclusions}

Summarizing, we need to notice that the utility, aesthetic, and cultural values of the dual architecture in Pomerania remained under a strong influence of authorities and political factors during the Prussian-German and Polish periods. The influence intensified shortly after the takeover of Pomerania. In the case of Prussia, it was 1720-1806 (enlightened absolutism in Prussia), whereas in the case of Polish supremacy 1945-1958 (period during which concepts developed for the rebuilding of castles in Szczecin and Słupsk, a period of communist dictatorship until 1956). A characteristic feature of both periods was the strong centralized state power extending its influence to all spheres of social life. Political factors, however, were not the only ones that determined the form of ducal architecture.

During the Prussian period, a major role was also played by utility factors, which finally contributed to the destruction and diminished cultural values in a similar fashion to political factors (Table 1).

Table 1. Factors that contributed to the transformation of ducal castles in the Prussian-German period.

\begin{tabular}{|c|c|c|c|c|c|}
\hline Cause/Motives: & Factors: & & $\begin{array}{c}\text { Architectural and } \\
\text { Spatial Intervention }\end{array}$ & & Symbolic Action: \\
\hline \multirow{2}{*}{$\begin{array}{l}\text { Loss of previous } \\
\text { function }\end{array}$} & \multirow{2}{*}{ Utility factors: } & $\rightarrow$ & Demolishing & $\rightarrow$ & Blurred memory \\
\hline & & $\rightarrow$ & Interior rebuilding & $\rightarrow$ & Functional degradation \\
\hline \multirow{6}{*}{$\begin{array}{l}\text { Diminished role of } \\
\text { ducal castle as } \\
\text { symbol of } \\
\text { Pomerania's } \\
\text { independence }\end{array}$} & \multirow{6}{*}{ Political factors: } & $\rightarrow$ & Demolishing & $\rightarrow$ & Blurred memory \\
\hline & & $\rightarrow$ & Interior rebuilding & $\rightarrow$ & Functional degradation \\
\hline & & & & & Domination of new \\
\hline & & $\rightarrow$ & Exterior conversion & $\rightarrow$ & $\begin{array}{l}\text { authorities (architectural } \\
\text { forms associated with new } \\
\text { authority) }\end{array}$ \\
\hline & & & Removal of symbols & & Blurred memory \\
\hline & & $\rightarrow$ & $\begin{array}{l}\text { and remnants of } \\
\text { Griffin Dynasty }\end{array}$ & $\rightarrow$ & $\begin{array}{c}\text { Weakening of previous } \\
\text { local identity }\end{array}$ \\
\hline
\end{tabular}

The table above shows that activity driven by political factors focused on achieving symbolic effects and hitting existential and emotional values directly linked with social and cultural identity, as well as situational values connected with the attachment of a society to a given space. In this particular case, Prussian pragmatism and politically driven interest in spatial domination were subordinated to the same goal.

A similar relationship could be found in the case of the post-war activity of Polish authorities. Utility-driven conservation interventions fitted into the political motivation and became symbolic (Table 2).

Table 2. Factors that contributed to the transformation of ducal castles in the Polish period.

\begin{tabular}{|c|c|c|c|c|c|}
\hline Cause/Motives: & Factors: & & $\begin{array}{l}\text { Architectural and } \\
\text { Spatial Intervention }\end{array}$ & & Symbolic Action: \\
\hline \multirow{2}{*}{$\begin{array}{l}\text { Restoring utility, } \\
\text { aesthetic and } \\
\text { historical values }\end{array}$} & \multirow{2}{*}{$\begin{array}{l}\text { Conservation } \\
\text { factors: }\end{array}$} & $\rightarrow$ & $\begin{array}{c}\text { Removal of secondary } \\
\text { layers considered } \\
\text { valueless }\end{array}$ & $\rightarrow$ & $\begin{array}{l}\text { Removal of rebuilding } \\
\text { traces-burred memory of } \\
\text { its German past }\end{array}$ \\
\hline & & $\rightarrow$ & $\begin{array}{l}\text { Rebuilding and restoring } \\
\text { the most valuable artistic } \\
\text { form }\end{array}$ & $\rightarrow$ & $\begin{array}{l}\text { Restoring form of castle } \\
\text { dating back to the rule of } \\
\text { Griffin Dynasty }\end{array}$ \\
\hline \multirow{2}{*}{$\begin{array}{l}\text { Restoration of } \\
\text { historical values, } \\
\text { creation of new } \\
\text { cultural values }\end{array}$} & \multirow[b]{2}{*}{ Political factors: } & $\rightarrow$ & $\begin{array}{l}\text { Rebuilding and } \\
\text { highlighting the place of } \\
\text { the castle in urban } \\
\text { landscape }\end{array}$ & $\rightarrow$ & $\begin{array}{c}\text { Creating a symbol of "being } \\
\text { rooted" in the Recovered } \\
\text { Territory }\end{array}$ \\
\hline & & $\begin{array}{l}\rightarrow \\
\rightarrow\end{array}$ & $\begin{array}{l}\text { Development of cultural } \\
\text { role of the castle } \\
\text { Displaying artefacts } \\
\text { related to the Griffin } \\
\text { Dynasty }\end{array}$ & $\rightarrow$ & $\begin{array}{l}\text { Strengthening of Polish } \\
\text { culture in recovered land } \\
\text { Highlighting the affiliation } \\
\text { of the land to Polish culture } \\
\text { and politics }\end{array}$ \\
\hline
\end{tabular}


The rebuilding of the destroyed Griffin heritage, which as Polish authorities believed was previously "distorted", was an important act of national self-affirmation of the recovered territory. New utility and aesthetic values and a new form were designed to create new existential and symbolic values of ducal castles. This was meant to contribute to the integration of Poles with the area of Pomerania. While the Prussian activity aimed to strengthen the power over the territory and its local population, the Polish intervention involved the complete replacement of population and concentrated primarily on the integration of new settlers. Therefore, apart from the above-mentioned historical factors, the situation stimulated a negative attitude to the ducal heritage on the part of Prussian authorities and a positive attitude of the Polish administration.

Funding: This research received no external funding.

Acknowledgments: All images used in the article are public domain.

Conflicts of Interest: The author declares no conflict of interest.

\section{References}

Arlet, Joanna. 2017. Architektura Renesansowa jako przejaw prestiżu fundatora i pozycji twórcy. Szczecin: Wydawnictwo uczelniane Zachodniopomorskiego Uniwersytetu Technologicznego w Szczecinie, p. 152.

Bartetzky, Arnold. 2012. Nation—Staat—Stadt. Architektur, Denkmalpflege und visuelle Geschichtskultur vom 19. bis zum 21. Jahrhundert. Köln, Weimar and Wien: Böhlau Verlag, pp. 17-32.

Basista, Andrzej. 2009. Architecture and Values. Kraków: Universitas, p. 86.

Dziurla, Henryk. 1959. Szczecin Zamek. Jego dzieje i odbudowa. Szczecin: Prezydium Rady Okręgu Towarzystwa Rozwoju Ziem Zachodnich i Szczecińskie Towarzystwo Naukowe, pp. 73, 91-97.

Dziurla, Henryk. 2008. Konserwatorskie Refleksje. In Kreska i sercem. Edited by Ewa Kulesza-Szerniewicz and Beata Makowska. Szczecin: Stowarzyszenie Konserwatorów Zabytków, Krajowy Ośrodek Badań i Dokumentacji Zabytków, p. 75.

Fiuk, Piotr. 2017. Architektura Miasta Odbudowanego. Szczecin: Zachodniopomorski Uniwersytet Technologiczny w Szczecinie, pp. 63-64, 123.

Gołębiewski, Jakub Ignacy. 2008. W poszukiwaniu wpływu tradycji na urbanistyczny i architektoniczny kształt współczesnego Szczecina. In Kronika Szczecina 2007. Edited by Kazimierz Kozłowski. Szczecin: Wydawnictwo "Dokument" Oficyna Archiwum Państwowego w Szczecinie, pp. 141-42.

Gołębiewski, Jakub Ignacy. 2018. Krajobraz kulturowy skarpy odrzańskiej w Szczecinie. Przekształcenia historyczne i współczesne wyzwania w procesie jego kształtowania. In Architektura w krajobrazie: Harmonia—kompromis—konflikt. Edited by Weronika Kobylińska-Bunsch. Warszawa: Instytut Historii Sztuki Uniwersytetu Warszawskiego, p. 213.

Gwiazdowska, Ewa. 2006. Architektura na Pomorzu Zachodnim kształtowana w kręgu Karla Friedricha Schinkla i jego uczniów. In Schinkel i jego uczniowie na Pomorzu. Edited by Rafał Makała. Szczecin: Muzeum Narodowe w Szczecinie, p. 16.

Gwiazdowska, Małgorzata. 2016. Ochrona i konserwacja zabytków Szczecina po 1945 roku. Szczecin: Wydawnictwo Naukowe Uniwersytetu Szczecińskiego, pp. 185-86.

Jałowiecki, Bohdan. 2010. Społeczne wytwarzanie przestrzeni. Warszawa: Wydawnictwo Naukowe SCHOLAR, pp. 24-27.

Jarzewicz, Jarosław. 2019. Architektura średniowieczna Pomorza Zachodniego. Poznań: Wydawnictwo Naukowe UAM, p. 291.

Kroman, Krystyna. 1992. Dzieje architektury zamku od schyłku średniowiecza po czasy współczesne. In Zamek Ksiażęcy w Szczecinie. Edited by Hobbit s.c. Szczecin: Wydawnictwo GLOB, pp. 92, 95, 98, 101.

Labuda, Gerard. 1985. Dzieje Szczecina II. Warszawa-Poznań: Państwowe Wydawnictwo Naukowe, pp. 9-14.

Latour, Stanisław. 2008. Zamek Książąt Pomorskich w Szczecinie. Dzieje odbudowy po II Wojnie Światowej. In Kreska i sercem. Edited by Ewa Kulesza-Szerniewicz and Beata Makowska. Szczecin: Stowarzyszenie Konserwatorów Zabytków, Krajowy Ośrodek Badań i Dokumentacji Zabytków, pp. 51-72.

Machura, Zdzisław. 2004. Zamek Ksiażąt Pomorskich w Stupsku. Słupsk: Muzeum Pomorza Środkowego w Słupsku, pp. 7, 63 . 
Makała, Rafał. 2011. Między prowincja a metropolia. Szczecin: Muzeum Narodowe w Szczecinie.

Musekamp, Jan. 2013. Między Stettinem a Szczecinem. Metamorfoza miasta od 1945 do 2005. Poznań: Nauka i Innowacje, p. 160.

Nekanda-Trepka, Janusz. 1990. Zamek w Darłowie—przyczynek do badań nad działalnością budowlaną Książąt zachodniopomorskich. In Mecenat artystyczny Ksią̇ąt Pomorza Zachodniego. Edited by Władysław Filipowiak and Januszkiewicz Barbara. Szczecin: Muzeum Narodowe w Szczecinie, pp. 63-74.

Nekanda-Trepka, Janusz. 2008. Dwudziestowieczne przekształcenia skrzydła południowego Zamku Książąt Pomorskich w Szczecinie. In Sztuka XX wieku w Szczecinie i na Pomorzu Zachodnim. Edited by Rafał Makała and Maria Glińska. Szczecin: Muzeum Narodowe w Szczecinie, Stowarzyszenie Historyków Sztuki, pp. 99-112.

Norberg-Schulz, Christian. 1999. Znaczenie w architekturze Zachodu. Warszawa: Murator, pp. 42-43.

Ochendowska-Grzelak, Barbara. 2018. Odbudowane-Nieodbudowane. Paper presented at the Ogólnoposla LXVI Sesja SHS Szczecin, Niepodległość i nowoczesność, Szczecin, Poland, November 22-23; pp. 2-6.

Paszkowska, Małgorzata. 1992. Nikodema Tessina Młodszego projekt przebudowy zamku szczecińskiego na pałac barokowy. In Zamek Ksiażęcy w Szczecinie. Edited by Hobbit s.c. Szczecin: Wydawnictwo GLOB, pp. 117-28.

Piskorski, Czesław. 1946. Zabytki piastowskiego Szczecina. Szczecin: Spółdzielnia Wydawnicza „Polskie Pismo i Książka".

Piskorski, Jan M. 1999. Epoka wielkich przemian (do 1368 r.). In Pomorze Zachodnie poprzez wieki. Edited by Jan Piskorski. Szczecin: Zamek Książąt Pomorskich, pp. 57-92.

Praczyk, Małgorzata. 2015. Materialne ślady minionej zależności i ich współczesne odczytanie w przestrzeni miejskiej Szczecina. Porównania 17: 125-26. [CrossRef]

Radacki, Zbigniew. 1976. Średniowieczne zamki Pomorza Zachodniego. Warszawa: Państwowe Wydawnictwo Naukowe, pp. 48-105.

Rewers, Ewa. 2005. Post-Polis. Kraków: Universitas, p. 294.

Słomiński, Maciej, Rafał Makała, and Małgorzata Paszkowska. 2000. Szczecin barokowy. Architektura lat 1630-1780. Szczecin: Stowarzyszenie Historyków Sztuki, Oddział w Szczecinie, pp. 91-96, 140.

Wallis, Aleksander. 1967. Socjologia wielkiego miasta. Warszawa: Państwowe Wydawnictwo Naukowe, p. 71.

Wallis, Aleksander. 1990. Socjologia przestrzeni. Warszawa: Niezależna Oficyna Wydawnicza, pp. 13-16, 28-30.

Wiśniewski, Jerzy. 1963. Szczecin w rękach pruskich. In Dzieje Szczecina. Edited by Gerard Labuda. Warszawa: Państwowe Wydawnictwo Naukowe, p. 429.

Zachwatowicz, Jan. 1948. Pomniki kultury polskiej na ziemiach odzyskanych—ich losy, ochrona i upowszechnienie. In Przegląd Budowalny Miesięcznik Poświęcony Sprawom Budownictwa. Organ Stowarzyszenia Zawodowego Przemysłowców Budowlanych R.P. Warszawa: Wydawnictwo Czasopism Technicznych NOT, vol. 7, pp. $244-54$.

Zachwatowicz, Jan. 1965. Ochrona zabytków w Polsce. Warszawa: Wydawnictwo Polonia, p. 46.

Zaremba, Piotr, and Halina Orlińska. 1965. Urbanistyczny rozwój Szczecina. Poznań: Wydawnictwo Poznańskie, p. 96.

Publisher's Note: MDPI stays neutral with regard to jurisdictional claims in published maps and institutional affiliations.

(C) 2020 by the author. Licensee MDPI, Basel, Switzerland. This article is an open access article distributed under the terms and conditions of the Creative Commons Attribution (CC BY) license (http://creativecommons.org/licenses/by/4.0/). 